\title{
RESPONSE OF YIELD AND YIELD COMPONENTS OF FABA BEAN (VICIA FABA L.) TO PHOSPHATE FERTILIZER GROWN UNDER CONDITIONS OF SUMMAIL DISTRICT-DOHUK GOVERNORATE
}

\author{
REZAN EsSa Musa \\ Dept. of Soil and water Development, Collage of Agriculture Engineering Sciences, \\ University of Duhok, Kurdistan region-Iraq
}

(Received: October 8, 2019; Accepted for Publication: February 17, 2020)

\begin{abstract}
Five faba bean genotypes was sown in season 2018-2019 at the field of College of Agriculture, Duhok University to study the effect of four levels of phosphate fertilizer on yield and its components. The experiment was laid out in factorial experiment using randomize complete block design with three replicates. The results exhibited that the faba bean genotypes, fertilizer phosphate and their interaction showed highly significant effects on yield and some agronomic traits of it. Also the results revaluated that the maximum grain yield was $(217 . \mathrm{g})$ recorded by Lattikia genotype whilst, lower grain yield was $(87.5 \mathrm{~g})$ obtained by Reina genotype at zero phosphate level. The interaction between faba bean genotypes and levels of fertilizer phosphate, gave highest grain yield $(\mathbf{2 8 8 g})$ which was recorded by Lattikia genotypes at $(46 \%$ $\left.\mathbf{k g ~} \mathrm{P}_{205} / \mathrm{ha}\right)$. The correlation delete it between grain yield and six agronomic traits. The results showed week positive or negative correlation among most of the studied parameters when positive correlation were found between grain yield and number of pods per plant and number of seeds per pod with values $(0.761$ and 0.706). The results revealed that an increasing grain yield, may be an increase in the number of pods per plant and number of seeds per pod which response to the additional levels of fertilizer phosphate.
\end{abstract}

\section{INTRODUCTION}

$\mathbf{F}$ aba bean (viciafaba L.) is one of the major leguminous crops grown in the world. Its important source of protein used as food for human consumption in developing countries and animal feed in advance countries (Malhotra etal). faba bean was play an important role in soil fertility restoration through crop rotation due to nitrogen fixation of atmosphere. In Kurdistan region faba bean is the major grain legumes cultivated with chick pea and lentils of faba bean (Hamed, 2003). It also plays an important role in increasing maintaining and recovering margined lands soil fertility especially in semi-arid regions. The yield of faba bean increased and its quality improved quality through improving agricultural practices such as fertilization with phosphorus and better genotype. Phosphorus is a major nutrient, especially for legumes. It is consider the second essential nutrient element for both plants and microorganism. In spite of the considerable addition of phosphorus to soil, the amount variable for plant is usually low. Phosphorus solubility and soil microorganism can play an important role in proving plant growth and phosphate up take efficiency by releasing phosphorus from rock or tri- calcium phosphorus. Many researchers showed positive effect of phosphorus fertilization on yield and yield components of faba bean (Abo et al 1996, Hamed, 2003; Mekail et al, 2005; Ahmed et al, 2007; and El - Gizaway and Mehasen, 2009).

Faba bean production is affected by different varieties or genotypes, so that many researchers studied the effect of genotypes on yield components of faba bean such as (Silim and sExena, 1992; Singh et al, 1992; Al Ghamdi, 2007; Osman et al; or Rajab et al, 2010 and Bakry et al, 2011).The present study was aim to estimate the response of faba bean genotypes to phosphorus fertilizer and yield and its effect on components.

MATERIALS and METHODS 
Field experiment was conducted during season 2018 - 2019 at the field of College of Agriculture, University of Duhok to evaluate response of yield and its Components five genotypes of Faba Bean to Phosphate Fertilizer.

The physiological and chemical soil analysis is presented in Table (1). The experiment was laid out in factorial experiment using Randomize Complete Block Design (RCBD) with three replications. Five faba bean genotypes were sown (Reina, Lattikia, Hudiba, Giza and Aquadoice) in rows spacing $30 \mathrm{~cm}$ between rows and $10 \mathrm{~cm}$ between plants. The date planting was (27/11/2018). Before seed bed preparation $\mathrm{P}_{205}$ fertilizer were added at the rats of $0,23,46$, and $69 \mathrm{P}_{20} \mathrm{~kg} / \mathrm{ha}$.

The data of following characters were collected from five random plant sapless from each row, Plant height $\mathrm{cm}$, first pod height, Number of main branches / plant,Number of secondary branches / plant, Number of seed / pod,
Seed yield / plant (g), 100 seed weight, Number of nodule / plant, roots.

The data were statistically analyzed using Minitab software package (16) subsequently. The leas significant difference (Cancun'sMultiple Range Test at 0.05 probability level was used to test the difference among mean values (Steel and Torrie, 1984).

\section{RESULTS AND DISCUSSION}

Analysis of variance for all traits in winter season for 2018-2019 are presented in Table 2.The results revealed that the faba bean genotypes,phosphorus levels and their interaction showed highly significant effects on yield, components and some agronomic traits, except days to $75 \%$ of flowering for interaction between faba bean genotypes and phosphorus levels, these results are in agreement with those found by (Yohannisetal.,2015 and Tekleetal,.2015).

Table (2): Analysis of variance values of grain yield, yield components and some agronomic traits for faba bean genotypes grow in winter season 2018-2019

\begin{tabular}{|c|c|c|c|c|c|c|c|c|c|}
\hline \multirow{2}{*}{ Source } & \multirow{2}{*}{ df } & \multicolumn{8}{|c|}{ Ms } \\
\hline & & $\begin{array}{c}\text { plant height } \\
\mathrm{cm}\end{array}$ & $\begin{array}{c}\text { The first pod } \\
\text { height } \mathrm{cm}\end{array}$ & $\begin{array}{c}\text { Days to } \\
75 \% \text { floweri } \\
\text { ng }\end{array}$ & $\begin{array}{l}\text { N.main } \\
\text { branches }\end{array}$ & $\begin{array}{c}\text { No ofnodules } \\
\text { plant }\end{array}$ & $\begin{array}{l}\text { No. of pod/ } \\
\text { plant }\end{array}$ & $\begin{array}{c}\text { No. of } \\
\text { seeds/po } \\
\text { d }\end{array}$ & $\begin{array}{c}\text { Grain } \\
\text { Yield plant } \\
(\mathrm{g})\end{array}$ \\
\hline Blocks & 2 & 13.95 & 6.867 & 0.87 & 0.11 & 22.87 & 0.229 & 0.01 & 60.20 \\
\hline $\begin{array}{l}\text { Phospho } \\
\operatorname{rus}(\mathrm{p})\end{array}$ & 3 & $329.62^{\star *}$ & $170.06^{\star *}$ & $98.86^{* *}$ & $2.46^{* *}$ & $2097.66^{\star *}$ & $136.22^{* *}$ & $1.09^{* *}$ & $9382^{* *}$ \\
\hline $\begin{array}{l}\text { Varieties( } \\
\text { v) }\end{array}$ & 4 & $1649.77^{\star \star}$ & $312.20^{\star \star}$ & $455.89^{\star *}$ & $6.87^{\star *}$ & $776.65^{\star \star}$ & $144.15^{\star \star}$ & $1.40^{\star *}$ & $15207.5^{\star *}$ \\
\hline PxV & 12 & $13-7^{\text {** }}$ & $7-63^{* *}$ & 7.46 & $0.69^{* *}$ & $46.27^{* *}$ & 13.34 & $0.15^{\star *}$ & $604.8^{* *}$ \\
\hline Error & 38 & 4.46 & 1.84 & 2.94 & 0.13 & 3.09 & 0.59 & 0.008 & 5.00 \\
\hline Total & 59 & & & & & & & & \\
\hline
\end{tabular}

Generally Statistical analysis exhibited that studied Genotypes were differ significantly in plant height trait as a result of adding different phosphate levels. Depending on the mean values of plant height an application phosphate fertilizer at rate $46 \mathrm{~kg} \mathrm{p} 205 / \mathrm{ha}$ gave the tallest plant height $114.7 \mathrm{~cm}$. This was differ from plant height which received other levels of phosphate fertilizer when Giza genotype were taller in plant height $122 \mathrm{~cm}$. but it was not considerably different from Giza Regarding to the interaction between faba genotypes and phosphorus levels, the Giza showed tallest plant height at phosphate fertilizer rate $46 \mathrm{~kg} \mathrm{p} 205 / \mathrm{ha}$ whereas. Reina exhibited the shorter plants $(91.7 \mathrm{~cm})$.Application of $\left(46 \mathrm{kgP}_{205} \mathrm{ha}\right)$ resulted in substantial enhancement in plant stature as compare with zero phosphorus application. This positive response could be attributed to better root growth due to phosphorus application that facilitated better absorption of soil moisture and nutrient resulting in taller plants in comparison with zero phosphorus application. The previous results are agreement with Gemechuetal,2006.

Table (3): Effects of fababean genotypes, phosphorous levels and their interaction on plant $(\mathrm{cm})$. 


\begin{tabular}{|c|c|c|c|c|c|c|}
\hline \multicolumn{7}{|c|}{ Genotypes } \\
\hline $\begin{array}{c}\text { Phosphorus } \\
\text { levels }\end{array}$ & Reina & Lattikia & Hudiba & Giza & Aguadolce & $\begin{array}{c}\text { Mean of } \\
\text { effect of } P \\
\text { levels. }\end{array}$ \\
\hline 0 & j 91.7 & fgh 102.7 & cde 115.0 & de 112.3 & hij 96.3 & d 103.6 \\
\hline 23 & ij 96.0 & cf 108.7 & cd 118.7 & bc 120.0 & hij 97.0 & c 108.1 \\
\hline 46 & hij 97.0 & de 112.3 & bc 120.7 & ab 125.3 & ghi 100.0 & b 111.1 \\
\hline 69 & hi 98.7 & de 113.3 & ab 125.7 & a 130.3 & eg 105.3 & a 114.7 \\
\hline $\begin{array}{l}\text { mean effect } \\
\text { of plant } \\
\text { height } \\
\text { varieties }\end{array}$ & d 95.8 & b 109.3 & a 120.0 & a122.0 & c 99.7 & \\
\hline
\end{tabular}

The mean with each column which got by the same latter are not significantly different.

The effect of faba bean genotypes, phosphorous levels and their interaction on the first pod height were shown in Table 4,the results in the same table in dictated that the first pod height increased with all fertilization phosphate levels and the maximum highest mean value of the first pod height was recorded by fertilizer level $69 \mathrm{~kg} \mathrm{P} 2 \mathrm{O} 5 / \mathrm{ha}$, which was $21.93 \mathrm{~cm}$. The faba bean genotypes were differ in their first pod height, the Giza genotype reveled the highest first pod height by $(24.75 \mathrm{~cm})$ as compared with the rest faba bean genotypes. Relying on the interaction between faba bean genotypes and fertilizer phosphate level the highest first pod height produced by Giza genotype at $69 \mathrm{~kg} / \mathrm{ha} \mathrm{P}_{205}$ increasing the first pod height by $13 \mathrm{~cm}$. Compared with the same genotype at zero fertilizer phosphate. The phosphate fertilizer was the key component for energy generation in plants, better growth were obtained due to response of faba genotypes to phosphate fertilization with phosphate fertilizer, which is low in the studied soil as well as due to its role in improving the growth of plant roots and shoots and its role in cell division because it is imager part of which is sources of energy.(Zafaret $a l, 2011)$.

Table(4): Effects of faba bean genotypes and phosphate fertilizer levels on the first pod height $\mathrm{cm}$

\begin{tabular}{crrrrrr}
\hline $\begin{array}{c}\text { Phosphorous } \\
\text { levels }\end{array}$ & Reina & Lattikia & Hudiba & Giza & Aquadoice & $\begin{array}{c}\text { Mean of } \\
\text { effect of } P \\
\text { levels }\end{array}$ \\
\hline 0 & j 10.00 & hij 13.00 & d-g 17.33 & de 18.67 & ij 11.33 & d 14.07 \\
\hline 23 & hij 12.67 & 14.67 & cd 19.33 & bc 23.00 & g-j 13.33 & c 16.60 \\
\hline 46 & e-i 14.67 & d-h 16.67 & b 23.67 & b 25.67 & e-i 14.67 & b 19.07 \\
\hline 69 & f-j 14.00 & cd 19.33 & b 26.67 & a 31.67 & def 18.00 & a 21.93 \\
\hline $\begin{array}{c}\text { Mean } \\
\text { genotypes }\end{array}$ & d 12.83 & c 15.92 & b 21.75 & a 24.75 & cd 14.33 & \\
\hline
\end{tabular}

The mean with each column which got by the same latter are not significantly different.

Table show the mean number of days to $75 \%$ flowering of faba bean genotypes differed worthily, where the Giza genotype flowered late (13-08) days, comparison with genotype Aquadoice. The results in Table 5, indicated that the mean of fertilizer phosphate affected significantly on days to $75 \%$ flowering with increasing the phosphorus rate decreased the period to flowering with 92.33 . For interaction between faba bean genotypes and fertilizer phosphate, the Reina genotypes recorded the minimum days to $75 \%$ flowering with 84.67 days at fertilizer rate $46 \mathrm{~kg} \mathrm{P}_{205} / \mathrm{ha}$. Similar results were denoted by Tekleetal., 2015. Variation in time to reach specific phenotypic stage is related to sensitivity of the genotypes to variation in the photo-thermal regions, thus affecting days to flowerings adaption to environment, and crop 
yield in diverse growing conditions (Aghaalikhaniet al., 2012). Different type of faba bean include, spring, winter and Mediterranean, exhibit various phonological traits therefore, induction and maintenance of flowering differ among these classes (Patric and Stoddard, 2010).

Table (5): Influence of faba bean genotypes, phosphorous levels and their interaction on days to $75 \%$

\begin{tabular}{ccccccc}
\hline \multicolumn{7}{c}{ flowering. } \\
\hline $\begin{array}{c}\text { Phosphorous } \\
\text { levels }\end{array}$ & Rejna & Lattikia & Hudiba & Giza & Aquadoice & $\begin{array}{c}\text { Mean of } \\
\text { effect of } P \\
\text { levels }\end{array}$ \\
\hline 0 & d-g 93.67 & abc100.67 & ab103.00 & a 104.67 & gh90.33 & a 98.47 \\
\hline 23 & ghi89.00 & cde97.33 & bcd98.67 & abc99.67 & fgh90.67 & b 95.07 \\
\hline 46 & ghi89.00 & c-f 95.67 & abc100.67 & abc99.67 & hi 86.00 & b 94.20 \\
\hline 69 & i 84.67 & efg92.67 & bc99.00 & abc100.33 & i 85.00 & c 92.33 \\
\hline Mean Verities & c 89.08 & b 96.58 & a 100.33 & a 101.08 & c 88.00 & \\
\hline
\end{tabular}

The mean with each column which got by the same latter are not significantly different.

Table (5) showed the effect of faba bean genotypes, phosphate fertilizer and their interaction on number of nodules per plant. For interaction between genotypes and phosphorus level the maximum number of nodules produce by Giza genotypes at $46 \mathrm{~kg} / \mathrm{ha} \mathrm{P}_{205}$ with value 97.33 . Phosphorus $\mathrm{CP} / \mathrm{plays}$ important roles in nodulation and biological nitrogen fixation, photosynthesis, and nutritional values of Legumes including faba bean (Haling et al., 2016, Makoudiet al., 2018). Also regarding to the number of nodules per plant, it appear that the applied levels of phosphate fertilizer affected significantly on the number of nodules per plant genotype, the results indicated that three levels of phosphorus affected on number of nodule per plant, their values ranged between (71.07 to 82.0). Depending on the faba bean genotypes. The Giza, genotype gave the higher number of nodules per plant, which was (81.75).

Table (6): Influence of faba bean genotypes, phosphorous levels on number of nodules per plant.

\begin{tabular}{ccccccl}
\hline \multicolumn{1}{c}{$\begin{array}{c}\text { Phosphorous } \\
\text { level hg/ha }\end{array}$} & Rejna & Lattikia & Hudiba & Giza & Aquadoice & $\begin{array}{l}\text { Mean of effect of } P \\
\text { levels }\end{array}$ \\
\hline 0 & i 52.00 & i 51.33 & i 56.33 & h 62.33 & i 54.33 & d 55.27 \\
\hline 23 & h 63.00 & fg 70.67 & cd 78.00 & bc 81.00 & h 62.67 & c 71.07 \\
\hline 46 & gh 67.00 & cde 77.67 & b 86.00 & b 86.33 & def 72.67 & b 77.93 \\
\hline 69 & fg 70.67 & c 78.33 & a 92.33 & a 97.33 & efg 72.33 & a 82.20 \\
\hline main Varieties & e 63.17 & c 69.50 & b 78.17 & a 81.75 & d 65.50 & \\
\hline
\end{tabular}

Mean with each column which got by the same latter are not significantly different.

The results in Table 6 revealed the influence of faba bean genotypes phosphorus levels and their interaction on number of branches per plant. Different phosphate rate substantially effect on number of branches per plant, the rate $46 \mathrm{~kg}$ $\mathrm{P}_{205} /$ ha produced the maximum number of branches and the Giza genotypes recorded the maximum number of branches while, the interaction between faba bean genotypes and phosphorus level the same genotypes exhibited the maximum number of branches at fertilize rate 46kg P205/ha Similar results were recorded by many researcher, as Ahmed etal. 2007, Rayabetal., 2010 and Bakry et.al, 2011.

Table (7): Effect of faba bean genotypes, phosphorous levels and their interaction on number of main branches /plant. 


\begin{tabular}{ccccccc}
\hline $\begin{array}{c}\text { Phosphorous } \\
\text { level }\end{array}$ & Reina & Lattikia & Hudiba & Giza & Aquadoice & $\begin{array}{c}\text { Mean of effect of } \\
\text { P levels }\end{array}$ \\
\hline 0 & e 3.0 & e3.3 & de4.0 & bcd 5.0 & bcd5.0 & b4.1 \\
\hline 23 & de 4.0 & de4.0 & de4.0 & abc5.7 & de4.0 & b4.3 \\
\hline 46 & de4.0 & de4.0 & de4.0 & ab6.0 & e3.3 & b4.3 \\
\hline 69 & cd4.7 & dc4.7 & cd4.7 & a6.3 & cd4.7 & a5.0 \\
\hline Mean varieties & b3.9 & b4.0 & b4.2 & a5.8 & b4.3 & \\
\hline
\end{tabular}

Mean with each column where got the same latter are not significantly different.

The results in Table (7) indicated clearly that there were significant differences in the mean number of pods per plant, the maximum value of the mean number of pod per plant was 24.65 at phosphorous level $46 \mathrm{kgP}_{205} / \mathrm{ha}$ while relying on the effect of genotype the maximum value was 28.08 recorded by Lattikia genotype, regarding to the interaction between faba bean genotypes and phosphorus level, the maximum obtain of mean value was 34.6 recorded by Lattikia genotype at $23 \mathrm{~kg} \mathrm{P}{ }_{20} / \mathrm{ha}$. The results were found to be in an agreement with (Boll e.tal., 2000 and Endalkachew et.al .2018) who found that phosphorus fertilizer application increased the number of pods per plant and this trait was the major gelid components which may be affected the final seed yield.

Table (7): Effect of faba bean genotypes, phosphorous levels and their interaction on number of pod per plant

genotypes

\begin{tabular}{|c|c|c|c|c|c|c|}
\hline $\begin{array}{l}\text { Phosphorous } \\
\text { level kg/ha }\end{array}$ & Reina & Lattikia & Hudiba & Giza & Aquadoice & $\begin{array}{c}\text { Mean of } \\
\text { effect of } P \\
\text { levels }\end{array}$ \\
\hline 0 & hi 17.23 & def 21.97 & fg 20.23 & i 16.5 & gh 19.2 & c 19.03 \\
\hline 23 & fg 20.73 & cd 23.5 & fg 20.53 & ghi 18.9 & efg 20.9 & b 20.91 \\
\hline 46 & d-g 21.13 & a 34.6 & bc 24.87 & fg 20.67 & bc 25.4 & a 25.33 \\
\hline 69 & fg 20.63 & a 32.27 & b 25.93 & d-g 21.27 & cde 23.17 & a 24.65 \\
\hline Mean varieties & c 19.93 & a 28.08 & b 22.89 & c 19.33 & b 22.17 & 22.48 \\
\hline
\end{tabular}

The mean within each column which got by the same latter are not significantly different.

The seeds per pod was vary remarkably among the genotypes and phosphorus nutrition. The results in table 8indicated that the lattikia genotype gave the highest mean of seeds perpod (3.842), while the mean fertilizer phosphate at rate $\left(46 \mathrm{~kg} \mathrm{P}_{205} / \mathrm{ha}\right)$ had the maximum seeds per pod which was3.493. For Interaction effect of faba bean genotypes and phosphorus levels on seeds per pod of faba bean also the date in table 9 showed that Lattikia genotypes was relatively superior 4.433 than Reina (3.233), Hudiba (3.267), Giza 3-00 and Aquadoice (3.433) at application of fertilizer phosphate $69 \mathrm{~kg} \mathrm{P}_{205} / \mathrm{ha}$. In general, as the seeds per pod is a genetic character and it influenced by phosphorus nutrition. Similar results were obtained by many 
researchers as Gemechuet al., 2006, Lupwayietal, 2011 and Endalkachew et.al, 2018.

Table (9): Influence of faba bean genotypes,phosphorous levels and their interaction on number of seeds per pod.

\begin{tabular}{|c|c|c|c|c|c|c|}
\hline \multicolumn{7}{|c|}{ genotypes } \\
\hline $\begin{array}{c}\text { Phosphorous level } \\
\mathrm{kg} / \mathrm{ha}\end{array}$ & Reina & Lattikia & Hudiba & Giza & Aquadoice & $\begin{array}{c}\text { Mean of effect } \\
\text { of } P \text { levels }\end{array}$ \\
\hline 0 & fg 3.000 & ef 3.100 & fg 3.000 & h 2.567 & fg 3.000 & c 2.933 \\
\hline 23 & $c-f 3.167$ & b 3.600 & ef 3.067 & gh 2.800 & def 3.133 & b 3.153 \\
\hline 46 & ef 3.100 & a 4.233 & cde 3.300 & bcd 3.400 & bc 3.433 & a 3.493 \\
\hline 69 & $c-f 3.233$ & a 4.433 & cde 3.267 & $\mathrm{fg} 3.000$ & bc 3.433 & a 3.473 \\
\hline Mean varieties & c 3.125 & a 3.842 & bl 3.158 & d 2.942 & b 3.250 & \\
\hline
\end{tabular}

The mean with each other column followed by the same latter are not significantly different.

Grain yield was statistically affected by faba bean genotypes and phosphorous levels Table (10). The highest grain yield was (2008)reported at phosphorous level $46 \mathrm{~kg} \mathrm{P}_{205} / \mathrm{ha}$, while lowest grain yield(139.19)was recorded by Zero phosphorus level. Faba bean genotypes also affected grain yield, maximum grain yield (217.1g) was obtained by Lattikia genotype whereas, the lowest grain yield recorded by Reina genotype with value $129.7 \mathrm{~g}$ The interaction between faba bean genotypes and phosphorus levels was founded to be significantly Table (10). Highest grain yield 288.g was recorded by
Lattikia genotype at $46 \mathrm{~kg} \mathrm{P}_{20} / \mathrm{ha}$ while, lower grain yield $87.5 \mathrm{~g}$ obtained by Reina genotype at zero phosphorus level. An increasing in the grain yield refer to an increase in the number of pods per plant and number of seeds per pod which were affected by addition of phosphorus level and also the kind of genotypes was more effective in grain yield,(table 8,9)the highest grain yields are often obtained when all the yield components are maximized. These results were agreed with those obtained by Boll et.al, 2000, Hamed, 2003, ELGizaway and Mehaseu, 2009 and En dalkachew et.al, 2018.

Table (10): Effect of faba bean genotypes, phosphorous levels and their interaction on grain yield per plant.

\begin{tabular}{|c|c|c|c|c|c|c|}
\hline \multicolumn{7}{|c|}{ genotypes } \\
\hline $\begin{array}{c}\text { Phosphorous level } \\
\text { kg/ha }\end{array}$ & Reina & Lattikia & Hudiba & Giza & Aquadoice & $\begin{array}{l}\text { Mean of } \\
\text { effect of } P \\
\text { levels }\end{array}$ \\
\hline 0 & Im 126.4 & f 172.9 & n 87.5 & j 141.5 & fg 167.3 & c 139.1 \\
\hline 23 & kl 132.2 & d 197.1 & gh 162.9 & ghi 160.7 & fg 167.5 & b 164.1 \\
\hline 46 & jk 135.4 & a 288.0 & e 188.6 & hi159.5 & b 228.2 & a 200.0 \\
\hline 69 & $\mathrm{~m} 124.6$ & c 210.3 & j 139.2 & i 155.0 & de 194.7 & b 164.7 \\
\hline Mean varieties & c 129.7 & a 217.1 & d 144.6 & c 154.2 & b 189.4 & \\
\hline
\end{tabular}

The mean with each column which got the same latter are not significantly different. 
correlation analysis for the yield of the studied faba been genotypes with six agronomic traits is an essential way to understand the association between yield and these traits and their interacted influence on each other, the results in Table (11) represented the simple coefficient between yield and some plants traits, the results showed varied correlation positive, negative and week) among most of parameters. positive significant correlation were found between grain yield and number of pods per plants, number of seeds per pod with values $\left(0.761^{* *}\right.$ and $\left.0.706^{* *}\right)$ while, the number of nodules per plant exhibited highly positive relationship with plant height and the first pod height with values $0.793^{* *}$ and $0.866^{* *}$ , also the number of branches per plant correlated with plant height, first pod height and number of nodules per plant and their value were $\left(0.575^{* *}\right.$, $\left.0.675^{* *}\right)$ and $\left(0.549^{*}\right)$ respectively, these results are in agreement with those reported by some other researchers (Alghamdi and Ali 2004,Chaieb et.al, 2010.and Tamene et.al,2015).

Table (11): Simple correlation coefficient between yield and among attributes of studied five faba bean genotypes ground under different phosphorous levels

\begin{tabular}{|c|c|c|c|c|c|c|c|c|}
\hline & $\begin{array}{c}\text { plant } \\
\text { height }\end{array}$ & $\begin{array}{c}\text { The first } \\
\text { pod } \\
\text { height }\end{array}$ & $\begin{array}{l}\text { date of } 75 \% \\
\text { flowering }\end{array}$ & $\begin{array}{c}\text { number of } \\
\text { nodules } \\
\text { plant }\end{array}$ & $\begin{array}{c}\text { number of } \\
\text { main } \\
\text { branches }\end{array}$ & $\begin{array}{c}\text { Grain } \\
\text { yield } \\
\text { per } \\
\text { plant }\end{array}$ & $\begin{array}{c}\text { No. of } \\
\text { pods per } \\
\text { plant }\end{array}$ & $\begin{array}{c}\text { No. of } \\
\text { seeds } \\
\text { per pod }\end{array}$ \\
\hline $\begin{array}{c}\text { The first pod } \\
\text { height }\end{array}$ & $0.910^{* *}$ & & & & & & & \\
\hline $\begin{array}{c}\text { date of } 75 \% \\
\text { flowering }\end{array}$ & $0.666^{\star *}$ & $0.502^{* *}$ & & & & & & \\
\hline $\begin{array}{c}\text { number of } \\
\text { nodules plant }\end{array}$ & $0.793^{* *}$ & $0.866^{* *}$ & $0.194^{*}$ & & & & & \\
\hline $\begin{array}{c}\text { number of main } \\
\text { branches }\end{array}$ & $0.575^{* *}$ & $0.675^{* *}$ & 0.222 & $0.549^{* *}$ & & & & \\
\hline $\begin{array}{c}\text { Grain yield per } \\
\text { plant }\end{array}$ & 0.062 & 0.003 & -0.164 & 0.266 & -0.104 & & & \\
\hline $\begin{array}{c}\text { No. of pods per } \\
\text { plant }\end{array}$ & 0.203 & 0.138 & -0.125 & 0.385 & -0.109 & $0.761^{* *}$ & & \\
\hline $\begin{array}{l}\text { No. of seeds } \\
\text { /pod }\end{array}$ & 0.071 & -0.004 & -0.253 & 0.271 & -0.115 & $0.706^{* *}$ & $0.901^{* *}$ & \\
\hline
\end{tabular}

*. **. Significant effect at 0.05 and 0.01 respectively.

\section{REFERENCES}

Abo,EL,a,A,A.A.EL-sayed and A.A.ELbender.1996.Effect of phosphate bio fertilizer phosphorous on growth,yield and nutrient up take of faba bean plants.J.Agric.Sei.Mansoura.Univ;21(2):477483.

AghaalikhaniM;Etemadi:FawA.F.Agir $\quad 10.2012$. Physiological basis of yield difference for grain sorgome physiological basis of yield difference for grain Sorghume in semiaridenvironment.agric.biol.sci;7.pp

Ahmed.M.A.and El-Abagy.2007. Effect of bio and mineral phosphorous fertilizer on the growth,productivity and nutritional value of some faba bean (viciafaba)cultivars in newly cultivated land J.ofappl.Sci;res ;3(6):408-420.
Alghamdi,S.2007. Genetic behavior of some selected faba bean genotypes. African crop science proceeding. 8:709-714.

Alghamdi .S.S and kh. Ali.2004. Performance of several newly bred faba bean lines.Egypt .5and m. plant breed .8:189-200.

Bakry.B.A,T.T.AElewa,M.F.el kara manr,m.S.Zedian and M.M Taufik.2011. Effect of row spacing on yield and it component of some faba bean varieties under newly RE-claimed sand soil condition. World journal of agricultural Science 7(1):68-72.

Boll and M.D A,K.H.MSiddiave and R.F Brennau 2000. Grain yield response of faba bean (viciafaba L.) to application of fertilizer phosphorous and zinc .Australian journal of experimental agriculture,40-849-857. 
Chaieb .N,Teixeira da silva .J.A.Bouslama 2010. Relation between seeds yield and some trats of faba bean. TheAfrican journal of plant science and biotechnology.4(special lssue2) 39-45.

EI-gizawy.n.nkh.b and S.A.S. Mhasen .2009 Response of faba bean to bio,mineral phosphorous fertilizer and foliar application with zinc. World applied journal .6(10):1359-1365.

Endalkachew.F,kibert. KG Melese. A am B obe. 2018. Yield of faba bean (viciafaba 2.) as affected by time mineral $\mathrm{p}$,farm yard manure compost and rhizobium in acid soil of lay gayint district, north western high lands of E.thiopia. Agriculture and food security.7-16.

Gemechu.K,J.Mussa ,and W.Tezera.2006 Faba bean (viciafaba L)genetics and breeding research in Ethiopia :A Review .In:Ali K ,Kenneni G ,Ahmed S ,Malhotra R, Beniwal s, makkoukkHalilamh (EDS.) Food and forage legumes of Ethiopia :progress and prospect. Proleeding of the work shop on food and forage legume addisAbaba,Ethiopia.

Haling .R.E,Yang,N Shadwell and R.J. Simpson .2016. Growth and root dry matter aalocation by pasture legumes and agrass with contrasting external critical phosphorous requirements plant soil .407:67-79.

Hamed .M.f.2003. Faba bean productivity as affected by zinc,phosphorous fertilizer and phophorein. Annual of

Sci;moshtohor,41(3);1159-1119.

Lupwayi.N.2;kennedy AC and Rmchiwa 2011. Grain legume impact on soil biological processes in sub -sahranAfrica .Africa journal of plant sciences .s 1-7.

Makoudie.B,A.Kabbadj,M.mouradi,L.Amenc,O.

Domergue, M.Blai and C.Ghoulam .2018. Phosphorous deficiency increase nodule phytase activity of faba bean -rhizobia symbiosis.Actaphysiol, plant.40:63.

Mekail,m.M,m.A.Magtouk,l.zanouny.M.Fouaad and S.M.Abd El-Aziz.2005. Response of corn and faba bean to bio-fertilization.miniaJ, of Agric. Res. And development,25(3):421-436.

\section{Nosto.N.K,B.B.Os borne ,Y.lekberg}

G.P.Asshe,C.S.Baliotti,S.porderand C.C Cleveland.2017.Nutrient acguisition. Soil phosphorous partitioning and competition among tress in alol and tropical rain forest. newphytol ;214:1506-1517.
Osman, A.A,S.O.yagoub and O.A Tut. 2010.Performance of faba bean (viciafaba 1)cultivars grow new agro-ecological regions of Sudan (south sudan ).Australian.J.basic and apple .sci;4(11)5516-5521).

Patrick.JW AND f.1 Stoddard .2010 Physiology of flowering and grain filling in faba bean .field crops res;15:pp.234-242.

Ragab,A.A,A. Eman ,Tantawy and Sh.M. Abd-ElRasoul .2010. Acomparison between traditional and recent bioinocula on grow and productivity of faba bean (viciafaba L.) grown in calcarcoussoil.internationalJ.Academic Res;2(4):245-253.

Silim,S.N. and M.C.Sexena . 1992. Comparative performance of some faba bean (viciafaba L.) cultivares of contrasting plant type. 2-growth and development in relation to yield .J.Agri.Sci.Camb.118(3)333-342.

Singh.S.P,N.P.Singh and R.K. Pandey. 1992 Performance of faba bean varieties at different densities .FABIC Newsletter .30.29-31.

Steel,R.G.D and J.H.Torric .1984. Principle and procedures of statistics. 2 ED .Pp(7277).Mcgraw Hill book co.INC.Singapore.

Tamence .T.,Gemechu.k,tadese.S and J.Mussa.2015. Yield stability and relationships among stability parameters in faba bean (viciafaba L)genotypes. The crop journal.3,4:258-268.

Tekle.EK,CV.Raghavaiah, Achavan and H.Ibrahim .2015. Effect of faba bean (viciafaba L) genotypes,plant densities and phosphorous on product ivity,nutrient uptake, soil fertility changes and economics in central high lands of ethopia .Int.J of life sciences .3:287-305.

Yohannis.D,Hkiros and W yirga .2015 In culation ,phosphorous and zinic fertilization effects on no culation, yield and nutrient uptake of faba bean (viciafaba L) grown on calcariccambisol of semi aridethiobia. J.of soil Science and environmental many ment.6:9-15.

Zafar.M,Abbasi, $\quad$ M.K,Rahin,N,Khalig.A, Shaheen.A,JamilM,andshahid.2011 Influence of integrated phosphorous supply and plant growth promoting rhizobacteria on growth nodulation, yield and nutrient uptake in phaselous vulgaris Afriva Journal of Biotechnology 10:6793-16807. 
يِينج يِيكهاتيّن بوماوهيى ييّيت باقلكا هاتنه جاندن ل وهرزيّ جاندنى 2018-2019 ل زهفيّيت ثهكولينيّت

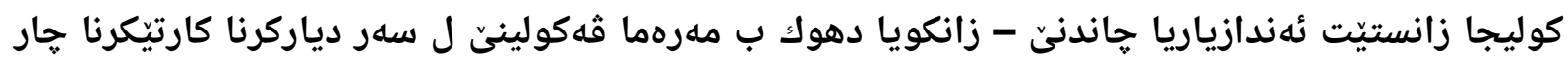
خهستيّت زبلى يـى فسفورى ل سهر جهنديا متايتّ باقلكا ويِيَكهاتنيّن وى. يه كهيّيت تاقيكرنيّ هاتنه ريّكخستن ب نهخشهزازيا كهرتيّن نهام ييّت رهمهكى, و ب دووبارهكرنا سيّ جاركى. دئهنجاميّت ثهكوليني دياركر كو

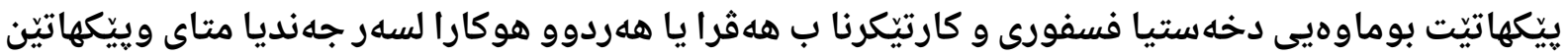
وى كارتيّكرنه كا ئهرينى هلبو لسهر ئهنجامان هلروهسا دئهنجامدا دياركر كو بلندترين متاييّ باقلا گه هشته

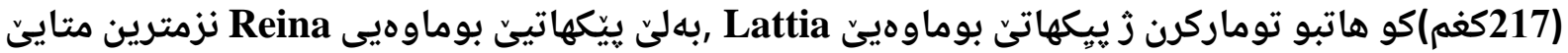

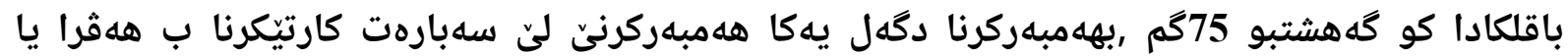

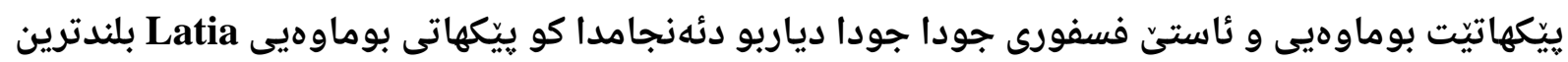

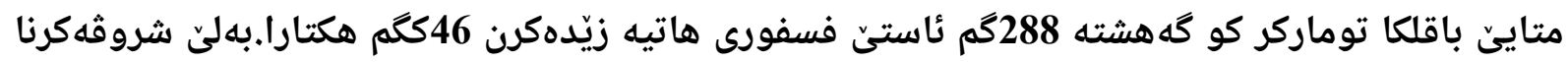

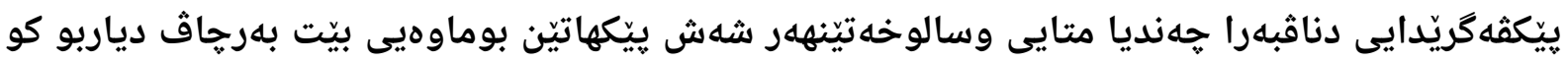

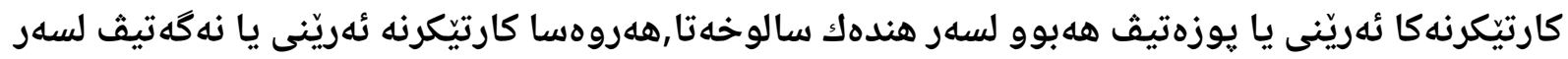

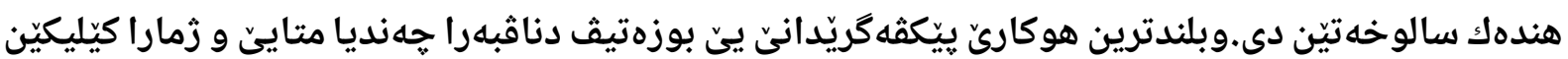
رووهكى 0,766-0,761 لديث ئيك.

استجابة الحاصل ومكوناته لبعض اصناف الباقلاء لمستويات من السماد الفوسفاتي

الخلاصة

زرعت خمسة تراكيب وراثية من الباقلاء في الموسم الزراعي 2018- 2019 في حقل كلية الزراعة / جامعة دهوك لدراسة تاثير اربعة تراكيز فسفورية على الحاصل ومكوناتة. وضعت الوحدات التجربية في تجربة

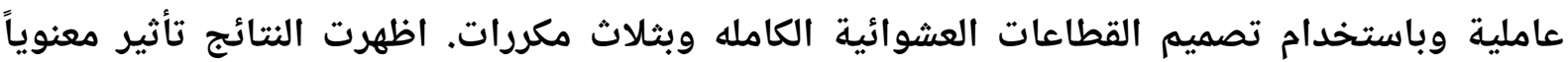
للتراكيب الوراثية والمستويات الفوسفاتية والتداخل بينها على الحاصل ومكوناتة كما بينت النتائج ان اعلى حاصل بلغ (217.1 غرام) والذي سجله التركيب الوراثي Lattia بينما سجل التركيب الوراثي حاصل بلغ 75 غرام وعند معاملة المقارنه اما التداخل بين التراكيب الوراثية ومستويات الفسفور المختلفه سجل التركيب Lattia اعلى حاصل بلغ 288 غرام تحت مستوى الفسفور 46 كغم هكتار 2os.اما تحليل

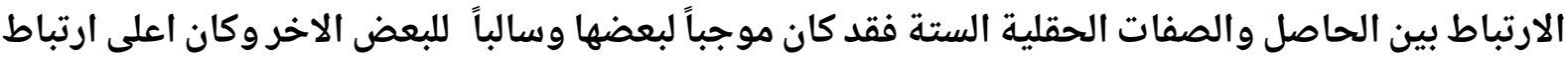
موجب بين الحاصل وعدد القرنات في النبات وعدد البذور في القرنه حيث بلغت قيمها 0.761 و0.766. 